\title{
Approaches to the Impact Evaluation \\ of Territorial Management Mechanisms \\ on the Change of Asymmetry \\ in Socio-Economic Development, \\ Life Quality and Economic Security \\ in the Resource Regions of the Country
}

\author{
Evgenia B. Bukharova, Svetlana A. Samusenko, \\ Anna R. Semionova and Ludmila K. Vitkovskaia* \\ Siberian Federal University \\ 79 Svobodny, Krasnoyarsk, 660041, Russia
}

Received 05.11.2016, received in revised form 09.11.2016, accepted 21.11.2016

The article describes methodological aspects of the analysis of asymmetry in the modern socioeconomic state of the resource regions in the Russian Federation as the result of historicallyshaped distribution of the production forces in the Socialist Siberia, implementation of privatization policy in the beginning of the 90s and currently existing instruments of tax regulation within the subsurface management, mechanisms for territorial administration and inter-budgetary relationships. Additionally, an integrated approach to the evaluation of inequality and asymmetry in the socioeconomic position of the resource regions in the context of life quality and economic security at both national and Siberian regional level has been considered.

The studies on the resource regions through the example of the Krasnoyarsk Territory are carried out in Siberian Federal University over the years and supported by the Russian Foundation for the Humanities under the grant project №15-12-24007 a(p) "Methodological Approaches to Formation of Applied Models of Analysis and Forecasting of the Economic Development for the Russian Resource Regions in the Context of Inequality and Asymmetry (the example of the Krasnoyarsk Territory)" and also supported by the Krasnoyarsk Territorial Fund for Scientific and R\&D Activities under the grant project "Methodological Approaches to Evaluation and Formation of the Structural Policy on Human Assets Reproduction to Ensure the Strategy for Sustainable Territorial Development of the Krasnoyarsk Territory in the Context of Diversified Technological Modernization of the Economy".

Keywords: resource economy, region, asymmetry in socio-economic development, economic security, economic policy, inter-budgetary relations, life quality.

DOI: 10.17516/1997-1370-2016-9-11-2653-2662.

Research area: economics, culture studies.

(C) Siberian Federal University. All rights reserved

* Corresponding author E-mail address: ebuharova@sfu-kras.ru; sv_sam@bk.ru; asemenova@sfu-kras.ru; vlk6759@mail.ru 


\section{Introduction}

The current problem statement is related to the development of new methodological approaches to shape development strategies for the subjects of the Russian Federation in the context of the national security efforts and achieve the long-term strategic goals in the socioeconomic development of this country [Strategiia natsional'noi bezopasnosti Rossiiskoi Federatsii. Utv. Ukazom Prezidenta RF ot 31.12.2015 № 683]. The article's baseline lies in the fact that the level of inequality and asymmetry of the socio-economic development of the territories is considered as a driver in the life quality and national security of the Russian Federation, and, moreover, it identifies threats to the economic security and resource regions, i.e. to the federal entities and the country per se. The life quality indicators are crucial in terms of the economic security evaluation [Strategiia natsional'noi bezopasnosti Rossiiskoi Federatsii. Utv. Ukazom Prezidenta RF ot 31.12.2015 № 683]. At the same time, the life quality and decrease in the number of threats to the regional economic security highly depend both on the public economic and social policy and on the business behavior in the resource regions.

\section{Conceptological framework}

Within this research, the regional economic security means a balanced state of economic, natural, cultural and ecological sub-systems of the region as a part of the general economic space of this country whereby threats to the national and regional sustainable development whether are absent or are tended to their alignment mainly through the changes in strategic priorities of the development, institutional transformations and investments into the priority projects implementation [Bukharov, Buharova et al, 2016]. An integrated evaluation of the regional economic security allow outlining the major disproportions and threats to the regional sustainability and identifying relationships between the leading spheres of economic security and different types of economic activity. The policy on the regional economic security is an action plan oriented on the stable development and enhancement of the regional economy basing on the mechanisms countering intra- and extra-threats. From the perspective of the economic security it is important not only to have instrumental schemes for the integral assessment and proactive impact of the expected threats, but also to be equipped to develop and apply a defense system aimed at the crisis phenomena avoiding.

\section{Problem statement}

On the national scale, one of the economic policy's directions is the reduction of socioeconomic inequality and disproportions between the regions with different types of economic profiles, i.e. industrial, resource, agricultural and finance-flows centring ones. In this way, a cross-regional asymmetry is not only aggravated under the recession, but also generates new disproportions and threats, mainly related to the inequality in the level of budgetary means, regional tax-income formation, average per capita incomes distribution and material inequality of the population. A significant risk for the economic security in the resource regions is posed by the ecological consequences of industrial expansion in the resource extraction which, on the one hand, is aimed at addressing the effects of crises, and, on the other, strengthens ecological risks and threats. Similar problems of inequality and asymmetry in the socio-economic state of regions are initially localized at the level of municipal entities and settlements within the region as a federal subject shaping a primary flow of imbalances and threats to the economic security. Yet, at the municipal and settlement level institutional and investment instruments of the economic security policy are 
extremely limited. In this article we will focus on a methodological approach to the analysis of influence of the territorial development mechanisms on changes in the asymmetry of socio-economic development, life quality and economic security level in the resource areas of this country through the example of the Krasnoyarsk Territory.

\section{Discussion}

The problems concerning asymmetry in the socio-economic development of the country in the sense of its territories have constantly been the focus of regionalists represented mainly by the Novosibirsk academic school of regional studies (A.G. Granberg, M.K. Bandman, V.I. Suslov, N.N. Mikheeva, V.E. Seliverstov and etc. [Granber et al , 2007; Mikheeva, 2009; Seliverstov, 2013]). It has almost been a truth that inhomogeneity of the economic space is peculiar to Russia due to its territorial length, natural and climatic conditions diversity and geopolitical factors as well. At the same time, within the period of industrial development, the economic inhomogeneity is considerably determined by the natural resources availability and infrastructural development of the territories, historically formed system of settlement and national mentality. Form the Czarist Russia till the present time, the evolution of Siberian regions has been linked to the solution of strategic governmental tasks on ensuring the resource security in this country. Exploration and development of Siberia can be regarded as a great campaign on the East for the resources. Due to this fact, the economy of the majority of Siberian regions has a pronounced resource character. Concurrently, during the Soviet period, the industrial picture of a number of Siberian regions including the Krasnoyarsk Territory was built also due to the deployment of defense contractors in these areas aimed at ensuring the strategic priorities in the geopolitical security.
Thus, at the beginning of 90 s the territorial socio-economic complex was structurally characterized as:

1. The place and role of the region in the national economy - an industrially developed region with the focus on the "national resource storage" and growth in the number of hi-tech enterprises.

2. Historically determined system of the national-economic relations and specialization of the region are based on the natural resources extraction and hi-tech production for the defense and industrial use. The economic structure was dominated by two types of production chains for the value creation. The resource-based industries were taken over by the extraction and low first stages of processing, and further high valueadded stages were performed in other regions. On the contrary, manufacturing activities, as a rule, missed the initial stages, and the Territory contained the final productions which had no sustainable system of multisectoral cooperation inside the region, and localization of the impacts was also concentrated outside the Territory owing to the state order.

3. There was a launch for the production chains on raw material advanced processing and high value-added production and, to some extent, oriented on intensification of the multisectoral cooperation inside the region in such types of economic activity as base chemistry, woodworking, metallurgy and civil engineering.

4. The structure of leading activities was characterized mainly by large manufacturing groups and enterprises.

5. The economic expansion on the natural resources development shaped a local system of settlement when the settled structure was formed closely relying on the centers of resource extraction ("mineral assets centered by settlements"). In this context, owing to a long meridional stretch of the territory the region had 
a low population density in the biggest part of northern and central districts. The concentration of settlements and high population density existed in the south district along the M-53 Federal Route and the Trans-Siberian Railway.

6. The infrastructural arrangement of the territory had also a local character and concentrated near the mineral development and extraction sites. Remoteness from the main residence areas of the country and market places was not balanced by the integrated transport network inside the region.

Figuratively speaking, the Territory was formed as a region for the national-aimed product manufacturing, and not as the one for the human living. Primarily this and several other factors have determined the high level of intra-regional asymmetry in the socio-economic position of the Territory's districts.

For the Krasnoyarsk Territory a transformation shift of this country into the market economy in the period 2006 - 2015 was, on the one hand, under a dynamic economic growth. Thus, over a decade, the average annual growth rates of manufacturing in this region have been 4.8 percentage points higher than in the national economy in general. On the other hand, the high economic growth has been caused by an extensive development mainly of the resource sectors (non-ferrous metallurgy, sectors of the fuel and energy complex, oil and gas extraction) that has significantly increased the intra-regional asymmetry, social and economic differentiation of the districts included into the Krasnoyarsk Territory and, moreover, has formed sound disproportions within the human capital re-production and life quality. The territorial economic security depends on the quality of human potential formed and driven by such aspects as: an ability to provide a particular level of well-being, life expectancy and healthy life-style, ensure the life and health protection, housing perspectives as well as opportunities for self-development determined by availability and sophisticated nature of the cultural and educational space.

The approaches to learn the quality of population's life in this region in the framework of economic security paradigm which includes the regional social security, are becoming more popular and are being actively elaborated [Abalkin, 1997; Kazantsev, 2014; Babenko, Blam et al, 2016]. The studies on the impact evaluation of asymmetry in the intra-regional economic development of the Krasnoyarsk Territory on the population life quality are based on the analysis of the indicator frameworks in terms of the strategic priorities and directions of the economic security policy in the Russian Federation [Strategiia natsional'noi bezopasnosti Rossiiskoi Federatsii. Utv. Ukazom Prezidenta RF ot 31.12.2015 № 683]. Under a multidimensional statistic analysis, in the context of four focus-groups there have been identified 24 indicators reflecting the quality of life in the given region. The average indicators on the socio-economic complex of the Krasnoyarsk Territory have been calculated basing on the data provided by the Federal Statistics Service (Rosstat) ${ }^{1}$. The obtained measurements on the Territory have been compared with the threshold values of the same indicators recommended by the international organizations for the developed market economies ${ }^{2}$ (Table 1).

Basing on the dynamic trend analysis and comparison between the average values of the life quality and the thresholds we have evaluated the tendencies in changes of indicators and identified problems and courses on streamlining or intensification of the threats to the regional economic security in the part of living standards and improvement of the human potential. One can outline the following two groups of key aspects of the population life quality in the given territory relating to its economic security: 
Table 1. Comparable degree between the thresholds of the indicators on the population life quality in the context of strategic priorities of the national security in Russia and the average values in the Krasnoyarsk Territory as at January 1, 2015

\begin{tabular}{|c|c|c|}
\hline Indicators & Thresholds & $\begin{array}{l}\text { Average value } \\
\text { in a decade }\end{array}$ \\
\hline \multicolumn{3}{|l|}{ Demographic indicators } \\
\hline Life expectancy, years & $\geq 75$ & 67,83 \\
\hline Total fertility rate & $\geq 2,15$ & 1,63 \\
\hline Mortality rate & $\leq 10$ & 13,23 \\
\hline Natural population growth to migration gain ratio & $\geq 1$ & $\mathbf{0 , 8 2}$ \\
\hline $\begin{array}{l}\text { Replacement ratio (number of children per } 1000 \text { inhabitants older than working } \\
\text { age) }\end{array}$ & $\geq 1000$ & 890 \\
\hline \multicolumn{3}{|l|}{ Environmental quality } \\
\hline General sick rate (initial cases per 1000 inhabitants) & $\leq 750$ & 808,43 \\
\hline Harmful emissions volume per capita, $\mathrm{t}$ & $\geq 0,015$ & 0,99 \\
\hline Share of workers employed in harmful and hazardous activities (in industries), $\%$ & $\leq \mathbf{3 0}$ & 52,93 \\
\hline \multicolumn{3}{|l|}{ Material inequality } \\
\hline $\begin{array}{l}\text { Share of expenditures on food products in the total amount of a mid-sized } \\
\text { household's expenditures , } \%\end{array}$ & $\leq 65$ & 26,28 \\
\hline Gini ratio & $\leq \mathbf{0 , 3 4}$ & 0,42 \\
\hline $\mathrm{R} / \mathrm{P} 10 \%$ ratio & $\leq 8$ & 16,64 \\
\hline Population incomes to expenditures ratio & $\geq 1$ & 1,09 \\
\hline Share of population with incomes below the subsistence level, \% & $\leq 7$ & 17,15 \\
\hline Per capita population incomes of the region to the Russian average ratio & $\geq 1$ & 0,96 \\
\hline \multicolumn{3}{|l|}{ Level of investment and availability of social services, housing facilities and transport } \\
\hline Gross enrollment rate for the professional education, $\%$ & $\geq 95$ & 68,93 \\
\hline Number of doctors per 10000 inhabitants & $\geq 48,6$ & 50,68 \\
\hline Share of investments in social sectors in the total amount of investments, $\%$ & $\geq 10$ & 2,84 \\
\hline $\begin{array}{l}\text { Share of Basic Production Assets of the social sectors in the total cost of Basic } \\
\text { Production Assets, \% }\end{array}$ & $\geq 10$ & 5,15 \\
\hline Residential area per one inhabitant, sq m & $\geq 45$ & 22,45 \\
\hline Share of households requiring the living conditions improving, $\%$ & $\leq 10$ & 3,46 \\
\hline Share of dilapidated housing, $\%$ & $\leq 5$ & 4,36 \\
\hline Total share of networks (waterlines, wastewater disposal, heating) \% & $\leq 5$ & 42,00 \\
\hline Availability of all kinds of transport measured through the Engel's curve (ratio) & $\geq 2$ & $\mathbf{0 , 4}$ \\
\hline Share of investment in the infrastructure in the total amount of investments, $\%$ & $\geq 15$ & 15,36 \\
\hline
\end{tabular}

- The aspects of population life quality positively influencing on the regional economic security;

- The aspects of population life quality in the Krasnoyarsk Territory causing threats to its economic security in the sense of the human potential decreasing.
In this, the trends in the population life quality changing which influence the regional economic security in a positive way relate to the indicators characterizing:

- High level of population incomes;

- Great promises in housing availability; 
- High level of investments in the infrastructure against the backdrop of total amount of investments;

- Relatively high level of cultural, healthcare and sport facilities availability.

Negative trends in the population life quality changes in the given territory posing threats to its economic security in the sense of the human potential reduction are linked to the indicators characterizing:

- Relatively low life expectancy;

- Increased general sick rate;

- Large share of workers employed in harmful and hazardous activities;

- Reducing gross enrollment rate for the professional education;

- Low share investments in social sectors in the total amount of investments;

- High differentiation of population incomes;

- High proportion of population with incomes below the subsistence level;

- Housing availability;

- Unfriendly ecological situation.

The screening of average values of the population life quality indicators in the context of strategic priorities of the national security of Russia and the given region together with their thresholds (Table 1) has indicated that only 5 indicators out of 24 meet the set level of security, and the vast majority - 19 items - are at risk that demonstrates the threat of the life quality decreasing in this territory. Such trend is proved by the rating of the Russian Regions on Life Quality in 2015, where the Territory has dropped from the $33^{\text {rd }}$ position to $43^{\text {rd }} .^{3}$

Such emerging tendency to the population life quality reduction in this territory has been determined not only by the historically formed role of the region within the national security, but rather by a number of fundamental institutional and financial reasons related to the mechanisms of territorial administration, tax management and business behavior.

1. Intensification of the influence of the public policy and strategies of minerals extracting companies on the strengthening of the resource specialization of the region. Over the last decade the industry structure of the Krasnoyarsk Territory's economy has rapidly been transforming towards the enhancement of extraction industries which have a low value added level froming the financial resources for the life level and quality growth.

2. Overrepresentation of a small number of large vertically-integrated companies in the resource industries which have financial responsibility centers outside this region, and the current system of taxation and fiscal management in the sphere of natural resources use do not create a competitive landscape and contribute to the export of the biggest part of added value and natural resources rent form the Territory. Streamlining of the income tax management on the basis of consolidated financial accounting provided by the leading corporations enhances the effect from the financial resources export. Thus, the regional budget losses evaluation is up to $10 \%$ per year. In fact, in these terms, the regional economic development related to the territorial natural resources exploration, is increasingly acquiring a "colonial character".

3. Primary development of the extracting productions and concentration of the corresponding economic activity, production assets and investment projects are dispersed selectively in the northern districts of the Territory that severely increase the asymmetry in the socio-economic state of the given region. Thus, the previous studies on the socio-economic asymmetry of the Krasnoyarsk districts based on the cumulative indexes of economic and social development of the municipal entities demonstrate a significant differentiation inside 


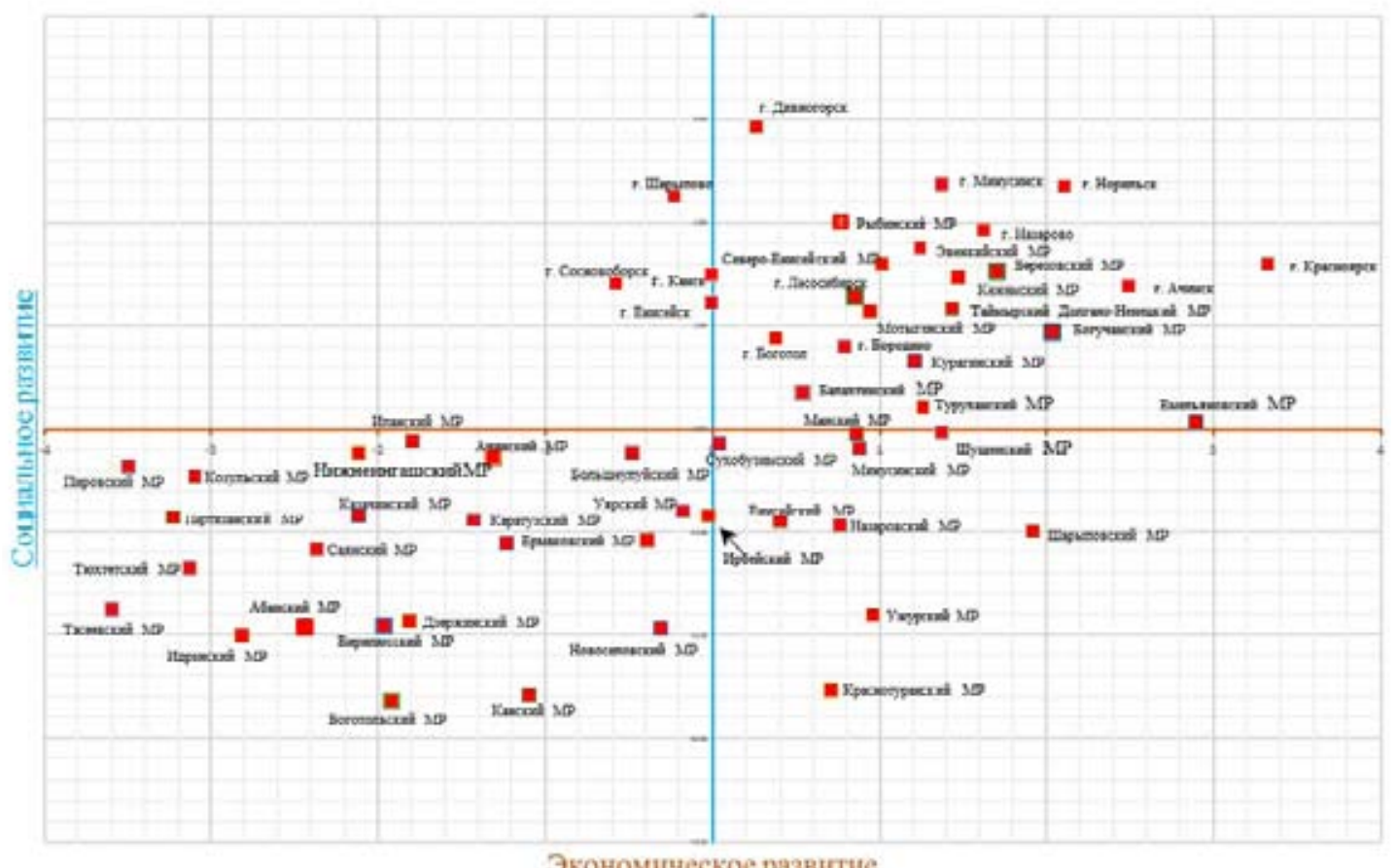

\section{Экономпческое развитие}

Fig. 1. Bi-dimension distribution of the municipal entities of the Krasnoyarsk Territory on the cumulative index of the economic development (X-line) and cumulative index of the social development (Y-line) in 2012 [Bukharov, Bukharova et al, 2015]

the given region Fig.1) [Bukharov, Bukharova et al, 2015].

The analysis of bi-dimension distribution of the municipal entities of the Territory on the cumulative indexes of social and economic development has showed a considerable differentiation of the regions' positions. At the same time, the number of sustainable regions on economic and social development lines $\left(1^{\text {st }}\right.$ square in the diagram, Fig.1; the level of socio-economic development is higher than the average territorial one) is not more than $33 \%$. Among the leaders characterizing by high positions over the last decade we name:

- Krasnoyarsk with its districts and towns included into the Krasnoyarsk Agglomeration;

- Norilsk;

- Territorial towns and districts included into the area of major investment project implementation: Lower Angara Region, the Vankor Field;
- Territorial towns with relatively high level of industrial development.

The share of "depressive" districts with the low level of both economic and social development ( $4^{\text {th }}$ square in the diagram, Fig.1; the level of socio-economic development is below the territorial average) is high and equals up to $30 \%$. They often include non-urbanized areas with the agricultural specialization.

4. Under the fiscal federalism the current system of norms and rules regulating interbudget relations between the regions and the federation causes the fact that the regions and the Krasnoyarsk Territory in particular, has no opportunity to accumulate the financial assets for the life quality improvement. Given that, the regions are dramatically losing the chances to enhance the fiscal incomes by themselves owing to capturing of the biggest part of collected tax incomes by the federal budget. In 2015, 54\% of 
all the tax incomes accumulated on the territory was transferred to the federal budget (in 2008 $23,5 \%$ ) that has 6 -times exceeded the amount of reverse transfers from the federal budget into the consolidated budget of the Krasnoyarsk Territory. Due to such a disbalanced budgetary policy in the Russian Federation, a non-consolidated public debt of the region has increased by more than 50 point over 9 years, and the relation of the regional public debt to the tax and non-tax incomes in 2015 has been accounted for 59,1\% and raised by $7 \%$ in comparison with 2014 . In the Russian rating of the subjects on debt load rate of 2015 the Territory has missed his positions and ranked $40^{\text {th }} .^{4}$

\section{Conclusion}

A highly-priority task in the economic security policy of the Krasnoyarsk Territory is an integrated challenge for the living standards and life quality improvement, creation of a comfortable living environment both from the perspective of population incomes, education and healthcare availability, and from the non- official relation of the authorities towards the human resources priority over the all other ones. The strategic vectors of the socio-economic policy of the resource regions are related to the encouragement of companies and regional government to invest into retaining and attracting new human assets, i.e. education, researches, healthcare and ecology across the whole territory. At the present time the regions are becoming a source for supporting and maintaining the economic sustainability in Russia basing on the human potential development. In this regard it becomes obligatory to monitor the tendencies in changes of the degree of the regional economic security in the context of a possible elaboration of the human potential and life quality. In this way, under the current economic situation in this country, the formation of even a basic level of conditions for the human potential enhancement and life quality improvement cannot be reached through the consolidation of efforts and resources just within a single region, but mainly, it should be determined by concerned authority actions of all levels and business communities.

For the indicator calculation primary statistic data formed in the United Interdepartamental Statistical Information System of Rosstat (https://www.fedstat.ru/) have been used.

2 For the thresholds assessments the values calculated on the developed market economies have been used. The primary statistic data have been taken from the Organization for Economic Cooperation and Development's statistic database: http://stats.oecd.org/

3 According to the data by RIA-rating "Rating of Regions on Life Quality - 2015": http://riarating.ru/.

4 According to the data by RIA-rating "Rating of Regions on Life Quality - 2015": http://riarating.ru/.

\section{References}

Abalkin L.I. (1997). Ekonomicheskaia bezopasnost' Rossii [The Economic Security in Russia], In Vestnik Rossiiskoi akademii nauk [Bulletin of the Russian Academy of Science], 9 (67).

Babenko T.I., Blam Ju.Sh., Kazantsev S.V., Kovaleva G.D., Korableva A.A., Lugacheva L.I., Marshalova A.S., Smirnova N.E., Soboleva S.V., Chudaeva O.V. (2016). Ugrozy i zaschischennost' ekonomiki Rossii: opyt otsenki [Threats and Security of the Russian Economy: Experience on Evaluation]. Novosibirsk, IEOPP SO RAN.

Bukharov A.V., Bukharova Ye.B., Vorontsova I.P., Gol'd M.V., Grib S.N., Grigorieva E.G., Zimniakova T.S., Krasnousov S.D., Muchkina E.Ia., Nepomniaschaia N.V., Popel'nitskaia I.M., Saviak N.N., Samusenko S.A., Semenova A.R., Ferova I.S. (2016). Ekonomika Krasnoyarskogo kraia: sistema regional'noi ekonomicheskoi bezopasnosti v usloviiakh krizisa [The Economy of the Krasnoyarsk Territory: System of Regional Economic Security in terms of Crisis]. Krasnoyarsk, Sib. feder. un-t. 
Bukharov A.V., Bukharova Ye.B., Vorontsova I.P., Gol'd M.V., Grib S.N., Grigor'eva E.G., Zimniakova T.S., Krasnousov S.D., Muchkina E.Ia., Nepomniaschaia N.V., Popel'nitskaia I.M., Saviak N.N., Samusenko S.A., Semenova A.R., Ferova I.S (2015). Ekonomika Krasnoyarskogo kraia: potentsial razvitiia i povysheniia konkurentosposobnosti [The Economy of the Krasnoyarsk Territory: Development Potential and Competitiveness Intensification]. Krasnoyarsk: Sib. feder. un-t.

Bukharova Ye.B., Samusenko S.A., Vcherashnii P.M. (2012). Tekhnologicheskaia mnogoukladnost' ekonomiki regiona: perspektivy i riski innovatsionnogo razvitiia [Technological Multistructurality of the Regional Economy: Perspectives and Risks of Innovation Development], 5, EKO.

Granber A.G., Suslov V.I., Suspitsin S.A. (2007). Mnogoregional'nie sistemy: ekonomikomatematicheskoe issledovanie [Multinational Systems: economic and mathematical investigation]. Novosibirsk: Sibirskoe Nauchnoe Izdatel'stvo.

Kazantsev S.V. (2014). Zashhishhennost' ekonomiki regionov Rossii [Economic Security of the Russian Regions]. Novosibirsk: IEOPP SO RAN.

Mikheeva N. N. (2009). Vozdeistvie mirovogo krizisa na strategiu prostranstvennogo social'noekonomicheskogo razvitiia Rossiiskoi Federactsii [The Global Recession Impac on the Strategy of Territorial Socio-Economic Development of the Russian Federation], In Region: ekonomika i sotsiologiia [Region: Economy and Sociology], 4.

Seliverstov V.E. (2013). Regional'noe strategicheskoe planirovanie: ot metodologii k praktike [Regional Strategic Planning: from Methodology to Practice]. Novosibirsk, IEOPP SO RAN.

Strategiia natsional'noi bezopasnosti Rossiiskoi Federatsii. Utv. Ukazom Prezidenta RF ot 31.12.2015 № 683 [The Russian National Security Strategy approved by the President's Order №683 of December 31, 2015].

\section{Подходы к оценке влияния механизмов}

территориального управления на изменение

асимметрии социально-экономического развития,

качества жизни и уровня экономической безопасности

ресурсных территорий страны

Е.Б. Бухарова, С.А. Самусенко,

А.Р. Семенова, Л.К.Витковская

Сибирский федеральный университет

Россия, 660041, Красноярск, пр. Свободныгй, 79

Статья посвящена методологическим аспектам анализа асимметрии современного социально-экономического состояния ресурсных регионов Российской Федерации как следствия исторического наследия размещуения производительных сил Сибири сочиалистического периода, реализации политики приватизации начала 90-х годов прошлого века и существующих в настоящее время инструментов налогового регулирования недропользования, механизмов территориального управления и межбюджетных отношений. Наряду с этим рассмотрен комплексный подход к оценке влияния неравенства и асимметрии социально-экономического 
положения ресурсных регионов на качество жизни и экономическую безопасность как наџиональной экономики в целом, так и самих ресурсных регионов Сибири.

Исследования ресурсных регионов на примере Красноярского края проводятся в Сибирском федеральном университете в течение ряда лет при поддержке РГНФ в рамках гранта № 15-12-24007 a(p) «Методологические подходы к формированию прикладньх моделей анализа и прогнозирования развития экономики ресурсных регионов России в условиях пространственного неравенства и асимметрии (на примере Красноярского края)», а также при поддержке Красноярского краевого фонда поддержки научной и научно-технической деятельности 6 рамках гранта «Методологические подходы к оченке и формированию структурной политики воспроизводства человеческого капитала для обеспечения стратегии устойчивого развития территорий Красноярского края в условиях диверсификации и технологической модернизаџии экономики».

Ключевые слова: ресурсная экономика, регион, асимметрии сочуиально-экономического развития, экономическая безопасность, экономическая политика, межбюджетные отночения, качество жизни.

Научная специальность: 08.00.00 - экономические науки, 24.00.00 - культурология. 